\title{
REMOTE WORKING CHALLENGES FOR GEORGIAN SOCIAL ENTERPRISES IN THE CONTEXT OF THE CURRENT PANDEMIC
}

\author{
Iza GIGAURI ${ }^{1 *}$ \\ Kakhaber DJAKELI ${ }^{2}$
}

Received: November 2021 | Accepted: November 2021 | Published: December 2021 Please cite this paper as: GHigauri, I.,Djakeli, K. (2021) Remote working challenges for Georgian social enterprises in the context of the current pandemic, Holistica Journal of Business and Public Administration, Vol. 12, Iss. 3, pp. 39-53

\begin{abstract}
The lockdown regulations aiming at avoiding the spread of the new coronavirus COVID-19 have caused disruptions in organizations of all types or sizes. In order to survive and remain competitive, enterprises have moved online. In line with the dramatic changes around the globe triggered by the regulations as a part of preventive measures, social enterprises switched to working from home. As a result, entrepreneurs have to learn new digital skills to capture the potential of digitalization as it is considered to have an ability to accelerate economic recovery after the pandemic. Yet digitalization influences organizational processes and operations and requires changes in strategies. In light of these transformations, researching social enterprises from different angles is of particular importance when economies are facing the threat of recession, as social entrepreneurship addresses market failure and can tackle social problems. Social entrepreneurs can find innovative solutions to modern challenges and help society and economies to transform. Therefore, this paper aims to investigate the feasibility of remote working and digitalization in social enterprises. The paper outlines remote working concerns in social enterprises in the Republic of Georgia and analyses flextime opportunities for enterprise employees. The empirical study is based on a qualitative research approach. In-depth interviews were conducted with the seventeen Georgian social entrepreneurs to explore the research questions. The paper contributes to understanding remote working in social enterprises and offers suggestions for future study directions in this under-researched area.
\end{abstract}

Keywords: social enterprise, entrepreneurship, remote work, flextime, Georgia, digitalization

\footnotetext{
${ }^{1}$ School of Business, Computing and Social Sciences, Saint Andrews Georgian University, Tbilisi, Georgia, E-mail: i.gigauri@sangu.edu.ge. ORCID: https://orcid.org/0000-0001-6394-6416

* Corresponding author

${ }^{2}$ Faculty of Business and Technologies, International Black Sea University, Tbilisi, Georgia, E-mail: kdjakeli@ibsu.edu.ge. ORCID: https://orcid.org/0000-0001-7505-5653
} 


\section{Introduction}

The New Normal since the outbreak of COVID-19 implied organizations to adapt their business models to reality when low-touch interactions occur through the digitalized business process (Gigauri, 2021; Vasile et al., 2021). The lockdown regulations aiming at avoiding the spread of the new coronavirus caused disruptions in organizations of all types and sizes. Telecommuting as a response to the Covid-19 pandemic gained popularity around the world. Although the tendency of using remote working and online systems as well as artificial intelligence in the organizational management processes has been increasing during the last decade, this trend become more vital due to the global pandemic (Gigauri, Gulua, \& Mushkudiani, 2020; Gulua, 2020; Djakeli, 2014). Organizations need to continue operations while keeping physical distancing and hence, they have been moving online. Consequently, enterprises have modified working conditions and accelerated digitalization to move online. The transition to remote working enabled them to continue operation to some extent. Private, public, and nonprofit organizations in line with the government recommendations allowed workers to stay at home and telecommute. Advances in information and communication technologies leading to digitalization have facilitated this transformation of work. Furthermore, digitalization is considered to have the ability to accelerate economic recovery after the pandemic. Therefore, organizations need to develop the digital skills of their employees in order to deal with uncertainties and achieve results.

Since lockdown policies are leading to recessions, the enterprising non-profit sector plays a vital role to solve social problems and contribute to economic activities. However, the pandemic has created exceptionally challenging conditions for social enterprises. For this reason, researching social enterprises from different angles is of particular importance when economies are facing the threat of recession as social entrepreneurship can address market failure and tackle social problems. Social entrepreneurs can find innovative solutions to modern challenges and help society and economies to transform. In this respect, it is important to study entrepreneurial challenges related to the COVID-19 pandemic, especially, from the social entrepreneurial perspective.

The aim of this manuscript is to investigate how social enterprises in Georgia modified work schedules since the pandemic. This study sheds light on the flex-time opportunities and remote working challenges in social enterprises as a response to external forces impacted by the COVID-19 pandemic.

The empirical study is based on a qualitative research approach. In-depth interviews were conducted with the seventeen Georgian social entrepreneurs to explore the research questions. The paper contributes to the knowledge in digitalization and remote working in social enterprises and paves the way for further comprehensive studies in this area. 
The rest of the paper is structured as follows. After the Introduction, Theoretical Background analyzes current literature on remote working and social entrepreneurship with the emphasis on the Georgian context. Next, the research methods and sample are described followed by the research results. Finally, the discussion and conclusion are presented along with the future research avenues.

\section{Theoretical Background}

Social entrepreneurship is a complex phenomenon owing to its dual - social and economic objectives. Social entrepreneurs strive to achieve a sustainable social impact and address the market simultaneously (Chinchilla \& Garcia, 2017). The importance of social entrepreneurship is increasing at the present time as society is facing unprecedented complexity of challenges (Chinchilla \& Garcia, 2017; Gigauri, 2018). Furthermore, young people devote gradually more attention to social issues and tend to choose a career according to inspirational purposes. The studies found out that many people between 18 and 34 years old prefer working in the social business rather than traditional for-profit companies (Bosma et al., 2016). Young people strive towards contributing to society and choose to work in an enterprise that gives them an opportunity to accomplish their purpose in doing something good for the world (Keohane, 2014). The young generation considers themselves as change agents in society offering enterprises the potential to enhance people's lives (Kolster, 2020), but also improve social, ecological, and economic conditions in a given country.

As a result of a global pandemic, countries, industries, and enterprises suffer dramatically due to synchronous decreases in demand and supply (Kraus et al., 2020). The Covid-19 pandemic forced organizations to modify work, adjust office design, change working policies, and most importantly, transition to teleworking (Parker, 2020; Webb et al., 2020). People and companies moved online, which enhanced the use of digital platforms to transfer works in digital space (Montgomery \& Baglioni, 2020). However, employee motivation, satisfaction, well-being, and in some cases also productivity decreased (Prodanova \& Kocarev, 2021). Therefore, remote working management has become a challenge around the globe. Organizations either extended their workplaces in the online dimension or adjusted physical workplace in such a manner to conform with the regulations, which suit the New Normal (Hou et al., 2021).

Recent studies suggest that organizations need to apply hybrid work models as employees prefer flexible work (Pataki-Bittó \& Kapusy, 2021; Wong et al., 2020), as remote work tasks, work environment, and work design determine the satisfaction and productivity of employees (Prodanova \& Kocarev, 2021; Wang et al., 2020). This, in turn, influences the decision of whether employees prefer remote work and home offices over the workplace office (Prodanova \& Kocarev, 2021). For this reason, access to digital tools and training are essential. Studies confirm that entrepreneurs continuously need to learn new digital skills, adopt digitalization not only in marketing but also in 
management systems and work processes to ensure business growth (Olsson \& Bernhard, 2020; Budnitz \& Tranos, 2021).

The pandemic forced people around the world to adapt to the new conditions by adopting digital technologies in almost all spheres of society from education to business. Organizations shifted to remote work, which facilitated digitalization as remote working tools have been rapidly developed along with the increasing demand (Yeganeh, 2021). Consequently, companies altered their business models to adapt their strategies to the changing environment (Kraus et al., 2020). Recent studies emphasize innovation and digitalization in this respect since the pandemic crisis led to adopting digital tools (Kraus et al., 2020; Huang \& Liu, 2020; Farivar \& Richardson, 2020). Furthermore, digitalization is considered as a means to tackle the crisis stemming from the current pandemic (Xiong et al., 2021; Ratten, 2021).

Moreover, scholars predict that the future of work lies in flexible and remote working from home, which gives also possibilities to disadvantaged groups, for instance, persons with disabilities, to be involved in the labour market (Martel et al., 2021; Morris, 2021).

Additionally, researchers consider that small and medium-sized enterprises can be disproportionately affected by the pandemic, as larger firms might be given preferences for goods when the supply chain is disrupted (Webb et al., 2020). As a result, small enterprises will be unable to produce efficiently. This applies also to social enterprises, which are vulnerable to external fluctuation and uncertainties. Therefore, social entrepreneurial efforts need to be focused on adopting digital technologies as well as introducing remote and flextime working.

\subsection{Remote Working and Social Entrepreneurship in Georgia}

Organizations in Georgia, applied digital tools, moved operations online, and switched to remote working as a response to the Covid-19 lockdown regulations (Gigauri, 2020b). As a result, also nonprofit and public organizations changed their policies in favor of remote and flexible working, which made it necessary for employees to improve technological skills (Gigauri, 2020a). However, previous research showed that many organizations in Georgia are not prepared to practice remote working and flexible schedules for all positions (Gigauri, 2020a). For this reason, both commercial and social enterprises require support in the transition process.

Although governments as a response to the pandemic economic consequences, abandoned free market ideologies to support business directly through tax and financial aid, wage subsidies, and sick pay regulations (Baum et al., 2020), social enterprises in Georgia were not offered any support. Notwithstanding, earlier studies emphasized that social entrepreneurial initiatives encouraged by governments have the ability to tackle problems and produce effective solutions (Gigauri \& Damenia, 2020). Since academics indicate unequal economic development in the regions and the capital city (Gechbaia et 
al., 2021), social enterprises, in this regard, can contribute to the sustainable development of Georgia.

At the moment, the entrepreneurial landscape in Georgia is characterized by the introduction of technological novelty. Last several years, many technological start-ups have been launching. Nevertheless, social entrepreneurship is still an undeveloped area in the country.

\section{Research Methodology}

According to Social Enterprise Alliance Georgia there are 63 social enterprises in Georgia (SEA, 2021). Therefore, a qualitative approach was considered as an appropriate research method for this study, and an in-depth interview technique was applied. All interviews with seventeen social entrepreneurs in Georgia were conducted on an online basis using online communication tools due to the pandemic imposing physical distancing and quarantine measures. The average duration of the interviews was 25 minutes. Interviews were recorded and transformed into the transcripts. Data was analyzed by thematic analysis tool and content analysis.

The interview guide was prepared beforehand, which enabled the researchers to react to the participants' statements (Eisenhardt \& Graebner, 2007; Neergaard \& Ulhøi, 2007).

The research question is twofold: (1) How social enterprises have operated since the new coronavirus pandemic, (2) and what social entrepreneurs think about remote working and flextime schedules.

The semi-structured interview guide involved four open-ended research questions that enabled gathering the necessary information:

(1) How have your employees worked since the COVID-19 pandemic?

(2) What do you think about the flextime work schedule in your social enterprise? Do you allow flex-time opportunities in your enterprise?

(3) Does your social enterprise allow remote working before and since the pandemic? Have you personally performed your work remotely since the pandemic? Did you personally work remotely before the pandemic? Do you retain remote working in your enterprise?

(4) Do you believe your employees are ready to work using new technologies and do they have digital skills?

The interview analysis followed the systematic method discussing themes, concepts, and categories, that emerged from the gathered data (Silverman, 2000), which needs to be sorted and labeled in order to determine appropriate topics and make links with the study questions (Flick, 2014). 


\subsection{Sample Description}

The purposive sample technique was applied to recruit the participants (Guest et al., 2006). The sampling of interview participants followed a theoretical procedure and the judgment of the researchers to engage respondents who can express thoughts and provide an explanation regarding the research questions. Respectively, the aim is not to enhance statistical validity but to obtain relevant and valuable information (Chase \& Murtha, 2019).

The size of the sample was determined by the concept of saturation that suggests that interview sessions are terminated when gathered data do not generate new themes or insights (Corbin \& Strauss, 2014; Cooper \& Schindler, 2014; Boddy, 2016; Morse et al., 2002).

The respondents represented social entrepreneurs in Georgia, who are founders or directors of the enterprises and hence, enabled the researchers to gain insights into research questions. The recruitment process contained the identification of potential respondents through the collaboration of Social Enterprise Alliance Georgia, contacting them through Emails and Social Media, and asking for an interview.

The majority of interview participants are men and are directors or founders of social enterprises (Table 1). The age of the respondents ranges from 25 to above 55 (Figure 1).

Table 1 Background of the Interviewees

\begin{tabular}{llll}
\hline Respondent & Age & Gender & Interviewee's Position \\
\hline R1 & $45-54$ & Men & Founder \& Director \\
\hline R2 & $55+$ & Women & Founder \& Director \\
\hline R3 & $25-34$ & Men & Director \\
\hline R4 & $25-34$ & Women & Director \\
\hline R5 & $25-34$ & Women & Founder \\
\hline R6 & $55+$ & Men & Manager \\
\hline R7 & $35-44$ & Men & Founder \\
\hline R8 & $25-34$ & Women & Director \\
\hline R9 & $25-34$ & Men & Founder \\
\hline R10 & $35-44$ & Men & Founder \\
\hline R11 & $25-34$ & Men & Co-Founder \\
\hline R12 & $35-44$ & Women & Director \\
\hline R13 & $35-44$ & Women & Founder \& Manager \\
\hline
\end{tabular}


HOLISTICA Vol 12, Issue 3, 2021, pp.39-53

\begin{tabular}{llll}
\hline R14 & $55+$ & Women & Director \\
\hline R15 & $25-34$ & Men & Director \\
\hline R16 & $55+$ & Men & Chairman \& Founder \\
\hline R17 & $55+$ & Men & Chairman \\
\hline
\end{tabular}

Source: Authors' own research

Figure 1 Interview Participants' Characteristics

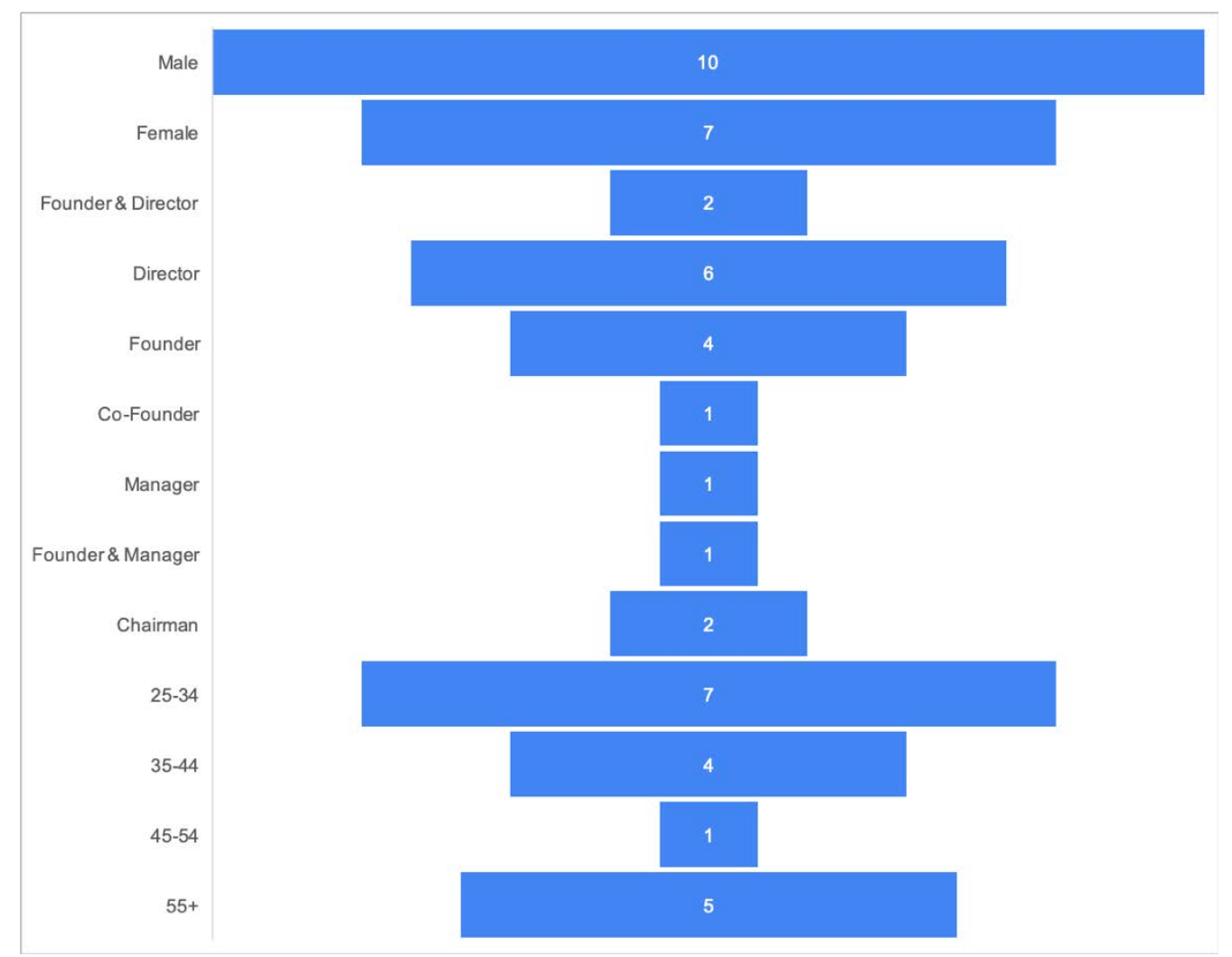

Source: Authors' own research

The respondents represented social enterprises that offer services or manufacture products (Table 2). They produce wooden toys, souvenirs, cloisonné enamel products, home textiles, linen and handmade items, the release of audio and multi-books, process berry crops farmed in the greenhouse to make jam, confiture, and compote. Environmental social enterprises produce Caucasian fir tree seedlings, collect and separate waste to create eco-friendly products from recycled paper, and develop accessories, clothes, and decorations from textile waste. 
HOLISTICA Vol 12, Issue 3, 2021, pp.39-53

With regard to the service, social enterprises offer training for local women in handicraft embroidery, and felt, as well as in sewing, embroidery, and thermal-transfer silkography. They also perform culture-educational activities, provide accommodation and cafés, offer inclusive preschool education, and parents' school, identify early developmental disorders in children of 0-7 by in-depth assessment, and ensure their involvement in pre-school and educational programs, as well as make recommendations for their parent, and caregivers.

All enterprises are small in size, and the number of employees ranges from 2 to 20 . In general, social enterprises in Georgia are small.

Table 2 Overview of Interviewed Social Enterprises

\begin{tabular}{|c|c|c|}
\hline Nature of the Enterprise & Year of Foundation & Number of Employees \\
\hline Produce table salt & 2013 & 7 \\
\hline Accommodation and café for tourists & 2020 & 4 \\
\hline Provide services - café & 2019 & 14 \\
\hline Café & 2016 & 14 \\
\hline Culture-educational activities & 2017 & 4 \\
\hline $\begin{array}{l}\text { Make jam, confiture, and compote of } \\
\text { strawberries farmed in the greenhouse }\end{array}$ & 2015 & 5 \\
\hline Produce wooden toys & 2016 & 20 \\
\hline Make souvenirs & 2015 & 17 \\
\hline Production of Caucasian fir seedlings & 2016 & 2 \\
\hline $\begin{array}{l}\text { Create products of textile waste such as } \\
\text { accessories, clothes, decorations }\end{array}$ & 2020 & 6 \\
\hline $\begin{array}{l}\text { Create Eco-friendly products of recycled } \\
\text { paper }\end{array}$ & 2017 & 8 \\
\hline Create cloisonné enamel products & 2012 & 6 \\
\hline
\end{tabular}


Produce home textiles, bed linen, 2017 4 handmade items; Offer training component to local women in handicraft, embroidery, and felt

Detection of developmental disability in 2017 20 children and make recommendations

\begin{tabular}{lcc}
\hline Producing wooden toys & 2018 & 14 \\
\hline $\begin{array}{l}\text { Training in sewing, embroidery, and } \\
\text { thermal-transfer silkography }\end{array}$ & 2016 & 7 \\
\hline $\begin{array}{l}\text { Release of audiobooks and video comics } \\
\text { (multi-books) }\end{array}$ & 2011 & 7 \\
\hline
\end{tabular}

\section{Source: Authors' own research}

The study covered the social enterprises founded almost every year from 2011 to 2020. Among them, four enterprises were established in 2016 and another four - in 2017, while two of them were launched in 2015 and two - in 2020. The rest entrepreneurs started their social enterprises in 2011, 2012, 2013, 2018, and 2019, respectively (Figure 2).

Figure 2 Year of Foundation of Interviewed Social Enterprises

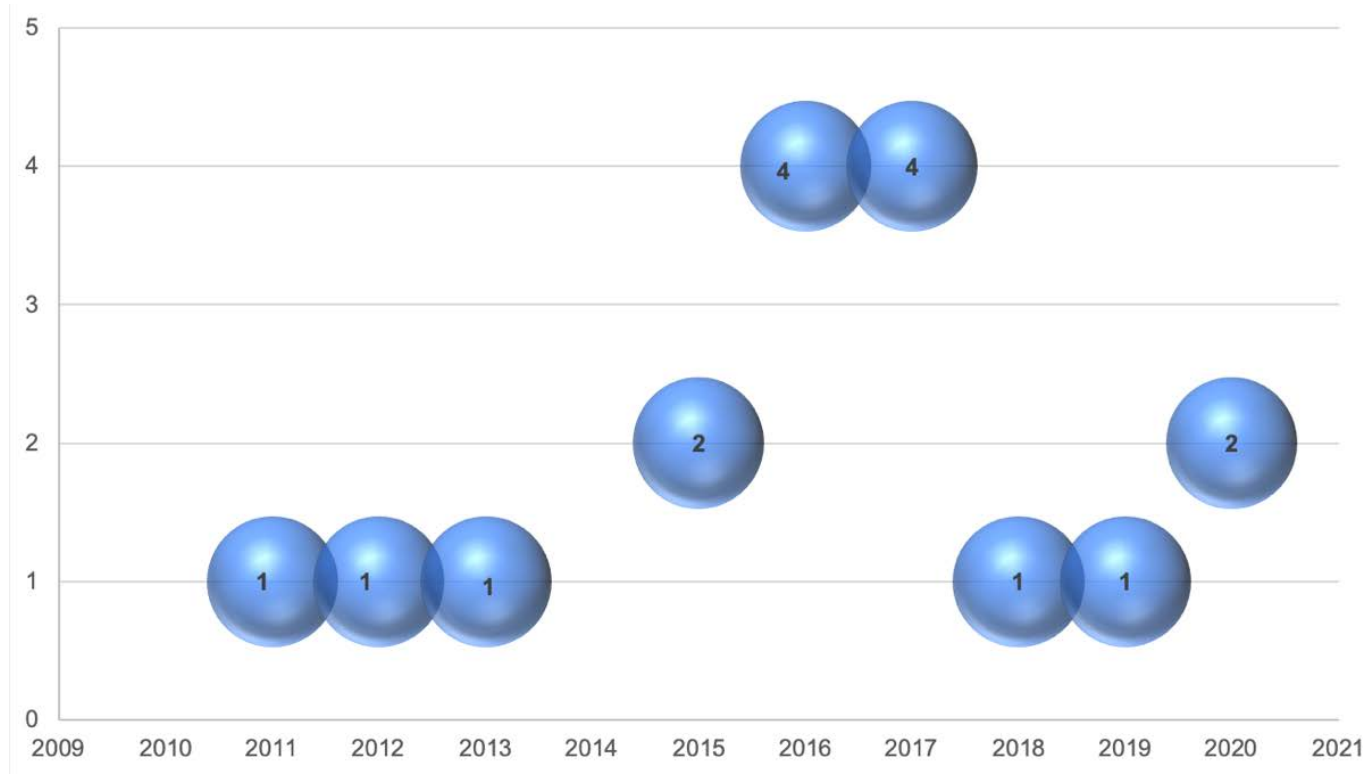

Source: Authors' own research 


\section{Research Findings}

The interview participants confirm the problems their social enterprises encountered because of the pandemic lockdowns. A particular challenge is to maintain employees and continue operating in the market. Yet, seven respondents stated that they did not dismiss employees during the pandemic and eight interview participants declared that their enterprises gave employees unpaid leave because of the lockdowns.

To the question, how have the employees worked since the new coronavirus pandemic in the enterprise, the respondents mentioned that they changed the working schedule in a way to enable employees to work in the enterprise without creating density and to be distributed. Interestingly, three respondents claimed to work in the same way as before without changing anything because of the pandemic. However, one social enterprise fully switched to remote work, and two of them have terminated operations temporarily during the lockdown. As the regulations loosened in Georgia in Summer 2021, the social enterprises have started working actively, but interview participants argued that their enterprises decided to remain remote.

"Basically, now we are starting to work intensively, everyone needs to be in place, it is very important" (R2).

"We are mostly on the remote again, but sometimes we work from the place" (R6).

"The employees of our enterprise work mainly at home since the pandemic. We take home the cut linen and hence, have less contact with each other" (R10).

The second research question investigated flextime schedule possibilities in the social enterprises in Georgia and the view of entrepreneurs in this respect. The study demonstrates that social enterprises in Georgia offered flextime schedules to their employees even before the pandemic $(n=7)$. Nevertheless, this opportunity was mainly intended for administrative staff or office jobs. Five respondents answered that their social enterprises introduced a flexible working schedule because of the pandemic crisis since the outbreak of Covid-19. Yet two directors stated during the interviews that flextime schedule is impossible at their enterprises.

"We could arrange flexible working only for some positions, as it is impossible for the majority of positions in our enterprise" (R12).

"We have had a flexible schedule even before, yet only for office i.e. administration staff. It is impossible for the majority of positions in our enterprise as they need to be in place because of the production process" (R1).

During another interview, a participant responded that although they have launched their enterprise after the outbreak of the new coronavirus, they still do not allow the flexible working schedule.

The third question examined the opinion of social entrepreneurs concerning remote working. Four interviewed directors of the social enterprises claimed that they often worked remotely before the pandemic, while eight participants worked only seldom, 
and five founders mentioned that they never worked remotely before. Nonetheless, since the pandemic and imposed lockdown regulations, they were forced to move online.

Thus, the majority of the surveyed social enterprises switched remote working at least partly due to the pandemic. Yet, still, five interviewed asserted that they personally have not been working remotely even after the pandemic.

"Remote working is only possible for the financial or administrative staff" (R8).

"Remote working is almost impossible for the Georgian social enterprises. Digitalization and automatization are unattainable at the moment as we need investments for the introduction of innovations, new technologies. We need support from the government and donor organizations for such modernization" (R1).

Still, the majority of the interview participants are of the opinion to retain remote working for eligible positions $(n=7)$ and three entrepreneurs remarked that this issue has not been yet solved and they will decide on it. Two interviewed founders are against the remote working schedule as ineffective and even useless for business processes in their enterprises.

The fourth research question explored employees' digital skills and their readiness to work with new technologies in the social enterprises in Georgia. The respondents believe that their employees are ready to work with new technologies, while six respondents admit that the personnel of their social enterprises need to improve skills in information technologies to perform their jobs effectively. The interview participants declare that the enterprises require particular support and help to strengthen the digital skills of their workers.

It is also worth emphasizing, that the interviewees mentioned that it is impossible to work with digital technologies in their social enterprises due to the specificity of the dayto-day activities, and hence, their employees never need digital skills to perform their duties.

"In our case, we can not work with digital technologies alone because of our activities and work characteristics; we must work in the building of the enterprise and be personally present" (R9).

The interviews revealed that the social enterprises in Georgia were not prepared for such a crisis, and have not received any support from the government.

Interestingly, the respondents did not elaborate that they need help or support in the development of the skills of their employees. They do not consider investments in employee development, mainly because they have more urgent problems concerning financial stability, and cannot link the financial success of the enterprise to employee development and engagement. 


\section{Discussion and Conclusion}

The research presented the practice of Georgian social enterprises in terms of work modifications during the COVID-19 pandemic and examined flextime and remote working strategies developed for the new normal.

The interviewed social entrepreneurs have not fully adopted digitalization and remote working as they believe it is unfeasible for their enterprises. The results indicate that social enterprises in Georgia, generally, were not able to adapt to the new reality and arrange workspace accordingly. The interviews revealed that the social entrepreneurs are more dependent on governmental recommendations, and consider returning to the traditional business-as-usual - to the old working habits. However, they definitely changed behavior and switched to home working where possible by taking work at home.

The digital workplace seems to become an inevitable trend. Modern organizations need to remain flexible and quickly adapt to uncertainties. Digital skills of the workforce play a vital role in organizational performance. Consequently, social enterprises need to cooperate with IT companies or IT teams to develop digital facilities, introduce new technologies, use digital platforms, modify workplaces, and improve the digital skills of employees.

Social enterprises in Georgia need to adapt to the New Normal and change strategies to better cope with the current challenges. Particularly, they should introduce advanced technologies to automate the process, improve employees' technological skills and move towards digitalization. Remote working systems enable social enterprises to continue the business process without interruptions in the rapidly changing world. Remote work, flexible schedule, and digital skills of employees will lead to survival and implementation of their goals.

In a broad sense, social entrepreneurs can recruit digital natives, young people with digital skills to keep up with digitalization. Generally, entrepreneurs learn by doing, and hence, entrepreneurship behavior includes constant learning. Thus, social entrepreneurs should embrace challenges and overcome the crisis by opening up opportunities in emerging digitalization.

The study limitation lies with its qualitative character, and therefore, the results are suggestive instead of conclusive. Further studies can build on these research findings to perform in-depth and large-scale analyses of social enterprises from the digitalization perspective in conjunction with remote working strategies. 


\section{References}

Baum, T., Mooney, S. K., Robinson, R. N., \& Solnet, D. (2020). COVID-19's impact on the hospitality workforce - new crisis or amplification of the norm? International Journal of Contemporary Hospitality Management, 32(9), 2813-2829. https://doi.org/10.1108/ijchm04-2020-0314.

Boddy, C. R. (2016). Sample size for qualitative research. Qualitative Market Research: An International Journal, 19(4), 426-432. https://doi.org/10.1108/qmr-06-2016-0053.

Bosma, N., Schøtt, Th., Rareness, S. \& Kew, P. (2016). Global Entrepreneurship Monitor (GEM). Special Topic Report Social Entrepreneurship. Global Entrepreneurship Research Association. www.gemconsortium.org.

Budnitz, H., \& Tranos, E. (2021). Working from Home and Digital Divides: Resilience during the Pandemic. Annals of the American Association of Geographers, 1-21. https://doi.org/10.1080/24694452.2021.1939647.

Chase, K. S., \& Murtha, B. (2019). Selling to Barricaded Buyers. Journal of Marketing, 83 (6), 2-20. https://doi.org/10.1177/0022242919874778.

Chinchilla, A., \& Garcia, M. (2017). Social Entrepreneurship Intention: Mindfulness Towards a Duality of Objectives. Humanistic Management Journal, 1(2), 205-214. https://doi.org/10.1007/s41463-016-0013-3.

Cooper, D. R., \& Schindler, P. S. (2014). Business Research Methods (12 ed.). New-York: McGrawHill Irwin.

Corbin, J., \& Strauss, A. (2014). Basics of qualitative research: Techniques and procedures for developing grounded theory. Sage publications.

Djakeli, K. (2014). Mission-Objectives Matrix (MOM) as an Innovative Tool of Marketing Audit. Journal of Business, 3(1), 37-40.

Eisenhardt, K.M. \& Graebner, M.E. (2007). Theory building from cases: opportunities and challenges. Academy of Management Journal, 50 (1), 25-32. https://doi.org/10.5465/amj.2007.24160888.

Farivar, F., \& Richardson, J. (2020). Workplace digitalisation and work-nonwork satisfaction: The role of spillover social media. Behaviour \& Information Technology, 40(8), 747-758. https://doi.org/10.1080/0144929x.2020.1723702.

Flick, U. (Ed.). (2014). The Sage Handbook of Qualitative Data Analysis. Sage.

Gechbaia, B., Kharaishvili, E., Mushkudiani, Z., Goletiani, K., \& Tsilosani, A. (2021). Challenges of sustainable and equal development of regions in Georgia. E3S Web of Conferences, 280, 11007. https://doi.org/10.1051/e3sconf/202128011007.

Gigauri, I. (2018). Social Entrepreneurship in Developing Countries: Case of Georgia. The USV Annals of Economics and Public Administration. 18, 1(27), 103-111.

Gigauri, I. (2020a). Challenges HR Managers Facing due to COVID-19 and Overcoming Strategies: Perspectives from Georgia. Archives of Business Research,8(11), 1-18. https://doi.org/10.14738/abr.811.9313. 
HOLISTICA Vol 12, Issue 3, 2021, pp.39-53

Gigauri, I. (2020b). Remote working concerns during the covid-19 pandemic. International Journal of Social Science and Economic Research, 5(10), 2803-2818. https://doi.org/10.46609/ijsser.2020.v05i10.005.

Gigauri, I., \& Damenia, N. (2020). Cooperation between Social Entrepreneurs and Government to Develop Solutions to Social Problems. Business and Economic Research, 10(3), 116. https://doi.org/10.5296/ber.v10i3.17383.

Gigauri, I., Gulua, E., \& Mushkudiani, Z. (2020). Current Advances in Digital Recruitment of Human Resources and its Potential for Companies. SEU \& Science, Conference Proceedings of the 1st International Online Scientific Conference "Contemporary Challenges to Economics and Business".

Gigauri. I. (2021). New Economic Concepts Shaping Business Models in Post-Pandemic Era. International Journal of Innovative Technologies in Economy. 1(33), https://doi.org/10.31435/rsglobal_ijite/30032021/7393.

Guest, G., Bunce, A., \& Johnson, L. (2006). How Many Interviews Are Enough? Field Methods, 18(1), 59-82. https://doi.org/10.1177/1525822x05279903.

Gulua, E. (2020). Trends, Challenges And Orientations Of Human Resource Management. Innovative Economics and Management, 7(1), 51-67. https://doi.org/10.46361/2449-2604.7.1.2020.51-67.

Hou, H. (Cynthia), Remøy, H., Jylhä, T., \& Vande Putte, H. (2021). A study on office workplace modification during the COVID-19 pandemic in The Netherlands. Journal of Corporate Real Estate, 23(3), 186-202. https://doi.org/10.1108/jcre-10-2020-0051.

Huang, H. and Liu, S.Q. (2020), "“Donate to help combat COVID-19!" How typeface affects the effectiveness of CSR marketing?", International Journal of Contemporary Hospitality Management, 32 (10), 3315-3333. https://doi.org/10.1108/IJCHM-05-2020-0462.

Keohane, K. (2014). Brand and Talent. Kogan Page Limited.

Kolster, T. (2020). The Hero Trap. Routledge.

Kraus, S., Clauss, T., Breier, M., Gast, J., Zardini, A., \& Tiberius, V. (2020). The economics of COVID-19: initial empirical evidence on how family firms in five European countries cope with the corona crisis. International Journal of Entrepreneurial Behavior \& Research, 26(5), 1067-1092. https://doi.org/10.1108/ijebr-04-2020-0214

Martel, A., Day, K., Jackson, M. A., \& Kaushik, S. (2021). Beyond the pandemic: The role of the built environment in supporting people with disabilities work life. Archnet-IJAR: International Journal of Architectural Research, 15(1), 98-112. https://doi.org/10.1108/arch-10-2020-0225.

Montgomery, T., \& Baglioni, S. (2020). Defining the gig economy: Platform capitalism and the reinvention of precarious work. International Journal of Sociology and Social Policy, 41(9), 1012-1025. https://doi.org/10.1108/ijssp-08-2020-0400.

Morris, F. (2021). Prospects for employment of persons with disabilities in the post-covid-19 era $\begin{array}{llll}\text { in developing } \quad \text { countries. Disability } \quad \text { Society, } & \text { 1-20. }\end{array}$ https://doi.org/10.1080/09687599.2021.1932757. 
Morse, J. M., Barrett, M., Mayan, M., Olson, K., \& Spiers, J. (2002). Verification Strategies for Establishing Reliability and Validity in Qualitative Research. International Journal of Qualitative Methods, 1(2), 13-22. https://doi.org/10.1177/160940690200100202.

Neergaard, H., \& Ulhøi, J. P. (2007). Handbook of Qualitative Research Methods in Entrepreneurship. Edward Elgar Publishing.

Olsson, A. K., \& Bernhard, I. (2020). Keeping up the pace of digitalization in small businessesWomen entrepreneurs. International Journal of Entrepreneurial Behavior \& Research, 27(2), 378-396. https://doi.org/10.1108/ijebr-10-2019-0615.

Parker, L. D. (2020). The COVID-19 office in transition: Cost, efficiency and the social responsibility business case. Accounting, Auditing \& Accountability Journal, 33(8), 1943 1967. https://doi.org/10.1108/aaaj-06-2020-4609.

Pataki-Bittó, F., \& Kapusy, K. (2021). Work environment transformation in the post COVID-19 based on work values of the future workforce. Journal of Corporate Real Estate, 23(3), 151-169. https://doi.org/10.1108/jcre-08-2020-0031.

Prodanova, J., \& Kocarev, L. (2021). Employees' dedication to working from home in times of COVID-19 crisis. Management Decision. https://doi.org/10.1108/md-09-2020-1256.

Ratten, V. (2021). COVID -19 and entrepreneurship: Future research directions. Strategic Change, 30(2), 91-98. https://doi.org/10.1002/jsc.2392.

SEA (2021). Social Enterprise Alliance Georgia. http://www.seageorgia.ge/en/.

Silverman, D. (2000). Doing qualitative research: A practical handbook. Thousand Oaks, CS: Sage.

Vasile, V., Panait, M., \& Apostu, S.-A. (2021). Financial Inclusion Paradigm Shift in the Postpandemic Period. Digital-Divide and Gender Gap. International Journal of Environmental Research and Public Health, 18(20), 10938. https://doi.org/10.3390/ijerph182010938.

Wang, B., Liu, Y., Qian, J., \& Parker, S. K. (2020). Achieving Effective Remote Working During the COVID-19 Pandemic: A Work Design Perspective. Applied Psychology, 70(1), 16-59. https://doi.org/10.1111/apps.12290.

Webb, A., McQuaid, R., \& Rand, S. (2020). Employment in the informal economy: Implications of the COVID-19 pandemic. International Journal of Sociology and Social Policy, 40(9), 10051019. https://doi.org/10.1108/ijssp-08-2020-0371.

Wong, A. H. K., Cheung, J. O., \& Chen, Z. (2020). Promoting effectiveness of "working from home": findings from Hong Kong working population under COVID-19. Asian Education and Development Studies, 10(2), 210-228. https://doi.org/10.1108/aeds-06-2020-0139.

Xiong, J., Wang, K., Yan, J., Xu, L., \& Huang, H. (2021). The window of opportunity brought by the COVID-19 pandemic: An ill wind blows for digitalisation leapfrogging. Technology Analysis \& Strategic Management, 1-13. https://doi.org/10.1080/09537325.2021.1979212.

Yeganeh, H. (2021). Emerging social and business trends associated with the Covid-19 pandemic. Critical Perspectives on International Business. https://doi.org/10.1108/cpoib05-2020-0066. 